\title{
ANALISIS PARTISIPASI NELAYAN \\ DALAM PROGRAM ASURANSI NELAYAN
}

\section{Analysis of Fisherman's Participation in Fishermen Insurance Program}

\author{
Muhammad Feriqo Asyya*), Ivanovich Agusta \\ Departemen Sains Komunikasi dan Pengembangan Masyarakat, Fakultas Ekologi Manusia, \\ Institut Pertanian Bogor, Darmaga Bogor 16680, Indonesia \\ *)E-mail: 1208 feri@gmail.com
}

\begin{abstract}
Community participation in the development process will be realized as a real activity if the realization of the factors that support. Many factors influence their participation, especially internal factors that encourage participation from within, because the community itself is the one who knows what it really needs at this time. In 2016, in order to protect fishermen the government launched a fishermen insurance program. Implementation of this program certainly can not be separated from the participation of the fishermen themselves. The objectives of this study were (1) to analyze the relationship between internal factor level and fisherman's participation level in fisherman's insurance program, and (2) to analyze the relationship between the level of participation of the fishermen and the fishermen's participation in the fishermen insurance program. This study uses a quantitative approach supported by qualitative data, using correlation test to determine the correlation between two variables. The unit of analysis in this study is individu. The results showed that the level of fishermen's participation in the fishermen's insurance program was high, seen from the indicators measured.
\end{abstract}

Keywords: ommunity participation, internal factors, insurance of fishermen

\begin{abstract}
ABSTRAK
Partisipasi masyarakat dalam proses pembangunan akan terwujud sebagai suatu kegiatan nyata apabila faktorfaktor yang mendukung ada. Banyak faktor-faktor yang mempengaruhi partisipasi mereka, terutama faktor internal yang mendorong partisipasi dari dalam, karena masyarakat sendiri lah yang mengetahui apa saja yang benar-benar dibutuhkannya saat ini. Pada tahun 2016, guna melindungi nelayan pemerintah meluncurkan program asuransi nelayan. Pelaksanaan program ini tentunya tak lepas dari partisipasi nelayan itu sendiri. Tujuan dari penelitian ini adalah (1) menganalisis hubungan antara tingkat faktor internal dengan tingkat partisipasi nelayan dalam program asuransi nelayan, dan (2) menganalisis hubungan antara tingkat bentuk partisipasi nelayan dengan tingkat partisipasi nelayan dalam program asuransi nelayan. Penelitian ini menggunaan pendekatan kuantitatif didukung data kualitatif, menggunakan uji korelasi untuk mengetahui hubungan antar dua variabel. Unit analisis dalam penelitian ini adalah individu. Hasil penelitian menunjukkan bahwa tingkat partisipasi nelayan dalam program asuransi nelayan tinggi, dilihat dari indikator-indikator yang diukur.
\end{abstract}

Kata Kunci: Asuransi nelayan, Faktor internal, Partisipasi masyarakat. 


\section{PENDAHULUAN}

Sebagai negara kepulauan, Indonesia memiliki garis pantai yang panjang. Indonesia merupakan negara maritim, dengan luas wilayah perairan $6.315 .222 \mathrm{~km}^{2}$ dengan panjang garis pantai $99.093 \mathrm{~km}^{2}$ serta jumlah pulau 13.466 pulau yang bernama dan berkoordinat (Akbar dan Huda 2017). Sekitar 0,30 juta $\mathrm{km}^{2}$ dari luas perairan tersebut, merupakan laut teritorial dengan luas perairan kepulauan mencapai 2,95 juta $\mathrm{km}^{2}$ (Adam 2015). Luas laut yang termasuk dalam zona ekonomi eksklusif mencapai 2,55 juta $\mathrm{km}^{2}{ }^{1}$ Wilayah kepulauan yang cukup luas dan panjang ini menjadi salah satu lokasi yang strategis untuk pengembangan ekonomi yang berbasis kelautan. Berdasarkan data KKP, hasil perikanan pada tahun 2017 merupakan yang tertinggi sejak lima tahun terakhir, yaitu mencapai 7,67 juta ton.

Bidang perikanan dapat dijadikan sebagai indikator yang baik bagi pengelolaan laut, karena di sektor tersebut terdapat sumber daya ikan yang sangat besar. Sehingga perikanan sebagai salah satu SDA yang mempunyai peranan penting dan strategis dalam pembangunan perekonomian nasional terutama dalam meningkatkan perluasan kesempatan kerja, pemerataan pendapatan dan peningkatan taraf hidup bangsa pada umumnya, nelayan kecil, pembudidaya ikan kecil dan pihak-pihak pelaku usaha di bidang perikanan dengan tetap memelihara lingkungan, kelestarian dan ketersediaan sumber daya.

Sumber daya manusia merupakan salah satu potensi dalam pembangunan yang berasal dari manusia dan segala aktivitasnya. Arti penting dari sumber daya manusia dalam pembangunan bisa dilihat dari relevansinya dengan salah satu prinsip dasar pembangunan masyarakat itu sendiri. Penting bagi sumber daya manusia yang memadai bagi kesejahteraan masyarakat untuk peningkatan taraf hidup yang lebih tinggi. nelayan tradisional dengan kualitas sumber daya manusia yang terbatas cukup sulit bertahan, ditambah mereka dihadapkan dengan persaingan dengan nelayan modern. Nelayan tradisional dapat bertahan dengan meminjam uang kepada kerabat atau tetangga, serta bisa mencari tambahan dari usaha yang lain seperti apa yang dilakukan nelayan di Pulau Harapan dengan membuka penyewaan jasa misalnya.

Menurut data Badan Pusat Statistik (BPS), pada Sensus Nelayan 2013, diperoleh jumlah rumah tangga perikanan tangkap adalah sebesar 864495 rumah tangga. Dari data tersebut, jumah rumah tangga perikanan tangkap di perairan umum sebesar 257903 rumah tangga dan jumlah rumah tangga perikanan tangkap di laut sebesar 610511 rumah tangga. Berdasarkan data BPS, jumlah nelayan miskin di Indonesia pada 2011 mencapai 7.87 juta, atau sekitar 25.14 persen dari total penduduk miskin nasional yang mencapai 31.02 juta orang 2 . Mubyarto, et.al (1984) menyebutkan bahwa masyarakat nelayan Indonesia adalah masyarakat termiskin dari kelompok masyarakat miskin lainnya (the poorest of the poor).

Beberapa problematika yang dialami oleh nelayan-nelayan kecil di Indonesia yaitu meliputi kurangnya akses bahan bakar bersubsidi, permodalan, pungutan liar, isu lingkungan, perlindungan jiwa dan kesehatan, cuaca ekstrem serta kebijakan-kebijakan yang tidak berpihak ke nelayan. Hampir 85\% nelayan di Indonesia didominasi oleh perikanan skala kecil yang beroperasi di sekitar perairan pantai ${ }^{3}$. Kontribusi nelayan skala kecil sangat besar dalam produksi perikanan tangkap, namun nelayan skala kecil masih diidentikkan dengan kemiskinan. Hal ini menunjukkan usaha perikanan skala kecil masih tidak efiesien, dimana upaya penangkapan melebihi ketersediaan dari sumber daya yang ada.

\footnotetext{
${ }^{1}$ Pusat Data, Statistik dan Informasi, Kementerian Kelautan dan Perikanan, Statistik Kelautan \& Perikanan 2011, Jakarta: Kementerian Kelautan dan Perikanan, 2013, hlm. 255.

${ }^{2}$ Triyanti R dan Firdaus W. 2016. Tingkat Kesejahteraan Nelayan Skala Kecil dengan Pendekatan Penghidupan Berkelanjutan di Kabupaten Indramayu. [Internet]. [29 Juli 2018]. Vol. 11(1): 29-43. Dapat diunduh di https://www.google.co.id/search?q=jumlah+dan+kesejahteraan+nelayan\&oq=jumlah+dan+kesejahteraan+nelayan\&aqs=chro me..69i57.9429j0j7\&sourceid=chrome\&ie=UTF-8\#
}

${ }^{3}$ Ibid. 
Bila dilihat dari segi politik ekonomi (Satria 2012) menyebutkan penyebab timbulnya permasalahan minimnya kemampuan pengelolaan dan kemiskinan nelayan yaitu: (1) nelayan Indonesia umumnya tidak memiliki akses modal dan akses teknologi yang diperlukan untuk memaksimalkan kinerjanya, (2) banyak nelayan Indonesia yang berstatus hanya sebagai buruh nelayan, (3) sulitnya nelayan mencari bank yang mau memberikan pinjaman sebagai modal, (4) adanya praktik penjarahan ikan secara illegal, (5) minimnya sinergi antara pemerintah dengan stakeholder yang berkepentingan, (6) penerapan peeraturan perundang-undangan yang dirasa kontraproduktif dengan usaha peningkatan kesejahteraan nelayan, (7) beberapa kebijakan pemerintah seringkali dinilai tidak sejalan dengan kepentingan kesejahteraan umum.

Namun demikian, profesi sebagai nelayan adalah profesi dengan risiko yang cukup tinggi. Nelayan pergi melaut dengan kapal-kapalnya ke tengah laut, menghadapi berbagai macam bahaya yang bisa mengancam keselamatan mereka seperti ombak, duri ikan, gigitan binatang laut, cuaca buruk, kecelakaan dalam melaut dan kejadian-kejadian yang tak terduga lainnya. Data yang diperoleh dari kesatuan patroli laut dan pantai (KPLP) dan komite nasional keselamatan transportasi (KNKT) menunjukkan bahwa kecelakaan kapal dari tahun 2010-2016 terdapattotal 54 kecelakaan pelayaran, dengan total korban meninggal sebanyak 337 jiwa.

Asuransi nelayan menjadi salah satu alternatif untuk menghadapi risiko nelayan dan sebagai bentuk kehadiran negara dalam melindungi rakyatnya. Pemerintah telah mengeluarkan sejumlah program berkaitan dengan asuransi untuk nelayan. Seperti Bantuan Premi Asuransi Nelayan (BPAN) yang hanya dikhususkan bagi nelayan kecil yang memiliki kapal berkapasitas kurang dari 10 gross ton (GT) dan sudah mengantongi kartu nelayan, serta ada pula Asuransi Jasindo. Di tahun 2017, KKP menargetkan Bantuan Premi Asuransi Nelayan bagi 500000 jiwa. Dengan nilai manfaat per orang berupa santunan untuk kecelakaan akibat aktivitas penangkapan ikan sejumlah 200 juta rupiah apabila menyebabkan kematian, 100 juta rupiah apabila menyebabkan cacat tetap, dan 20 juta rupiah untuk biaya pengobatan. Sementara untuk santunan kecelakaan akibat selain melakukan aktivitas penangkapan ikan, diberikan manfaat perorang sejumlah 160 juta rupiah apabila menyebabkan kematian (termasuk kematian akibat selain kecelakaan/kematian alami), 100 juta rupiah untuk yang mengalami cacat tetap, dan biaya pengobatan sebesar 20 juta rupiah. Program tersebut diselenggarakan guna melindungi nelayan dan pembudidaya ikan dari risiko yang dihadapi.

\section{Tujuan Penelitian}

Tujuan dari penelitian ini adalah sebagai berikut:

1.Menganalisis tingkat faktor internal dalam program asuransi nelayan.

2. Menganalisis tingkat bentuk partisipasi nelayan dalam program asuransi nelayan.

3. Menganalisis hubungan tingkat faktor internal dan bentuk partisipasi nelayan dalam program asuransi nelayan.

\section{PENDEKATAN TEORITIS}

\section{Nelayan}

Nelayan dapat diartikan sebagai orang yang hasil mata pencaharian utamanya berasal dari menangkap ikan di laut. Nelayan dalam Ensiklopedi Indonesia dinyatakan sebagai orang-orang yang secara aktif melakukan kegiatan penangkapan ikan, baik secara langsung maupun tidak langsung sebagai mata pencahariannya. Nelayan merupakan pekerjaan menangkap ikan di laut yang kebanyakan dilakukan oleh masyarakat nelayan yang tinggal di desa pesisir.

Masyarakat nelayan adalah masyarakat yang hidup, tumbuh dan berkembang di kawasan pesisir, yakni kawasan tradisi antara wilayah darat dan laut. Sebagai suatu sistem, masyarakat nelayan terdiri atas kategori-kategori sosial yang membentuk kesatuan sosial. Mereka juga mempunyai sistem nilai dan symbol-simbol kebudayaan sebagai referensi berperilaku sehari-hari.

Menurut Undang-Undang Nomor 45 Tahun 2009 tentang perikanan, nelayan adalah orang yang mata pencahariannya melakukan penangkapan ikan. Secara geografis, masyarakat nelayan adalah masyarakat 
yang hidup, tumbuh, dan berkembang di kawasan pesisir, yakni suatu kawasan transisi antara wilayah darat dan wilayah laut (Sipahelut 2010). Penelitian lain menyebutkan bahwa nelayan adalah orang yang secara aktif melakukan pekerjaan dalam penangkapan ikan atau binatang air (Ditjen Perikanan Tangkap Departemen Kelautan dan Perikanan 2007 dalam Patriana 2011). Dalam penelitian tersebut dijelaskan bahwa pekerja yang membuat jaring, pengangkut alat penangkapan ke dalam perahu tidak diartikan sebagai nelayan.

Satria (2002) menggolongkan nelayan menjadi 4 (empat) tingkatan yang dilihat dari kapasitas teknologi, orientasi pasar dan karakteristik hubungan produksi. Keempat tingkatan nelayan tersebut adalah: (a) Peasant-fisher atau nelayan tradisional yang biasanya lebih berorientasi pada pemenuhan kebutuhan sendiri (subsisten). Nelayan ini masih menggunakan alat tangkap yang tradisional, seperti dayung atau sampan tidak bermotor dan masih melibatkan anggota keluarga sebagai tenaga kerja utama.; (b) Post-peasant fisher, dicirikan dengan penggunaan teknologi penangkapan ikan yang lebih maju seperti motor tempel atau kapal motor. Penguasaan sarana perahu motor tersebut semakin membuka peluang bagi nelayan untuk menangkap ikan di wilayah perairan yang lebih jauh dan memperoleh surplus dari hasil tangkapannya karena mempunyai daya tangkap lebih besar. Umumnya, nelayan jenis ini masih beroperasi diwilayah pesisir. Pada jenis ini, nelayan sudah berorientasi pasar. Sementara itu, tenaga kerja yang digunakan sudah meluas dan tidak bergantung pada anggota keluarga saja; (c) Commercial fisher, yaitu nelayan yang telah berorientasi pada peningkatan keuntungan. Skala usahanya sudah besar yang dicirikan dengan banyaknya jumlah tenaga kerja dengan status yang berbeda dari buruh hingga manajer. Teknologi yang digunakan pun lebih modern dan membutuhkan keahlian tersendiri dalam pengoperasian kapal maupun alat tangkapnya; dan (d) Industrial fisher, ciri nelayan jenis ini adalah diorganisasi dengan cara-cara yang mirip dengan perusahaan agroindustri di negara-negara maju, secara relatif lebih padat modal, memberikan pendapatan yang lebih tinggi daripada perikanansederhana, baik untuk pemilik maupun awak perahu, dan menghasilkan untuk ikan kaleng dan ikan beku yang berorientasi ekspor.

\section{Partisipasi}

Secara etimologi, partisipasi berasal dari Bahasa Inggris "participation", atau dalam Bahasa Belanda disebut "participatie" yang berarti mengambil bagian/keikutsertaan, Kemudian, dalam Kamus Besar Bahasa Indonesia dijelaskan "partisipasi" berarti: perihal turut berperan serta dalam suatu kegiatan, keikutsertaan, peran serta. Sedangkan secara umum partisipasi berarti keterlibatan seseorang dalam suatu kegiatan guna mencapai suatu tujuan yang telah ditentukan.

Soetrisno (1995) dalam Sadly (2004) menyatakan bahwa partisipasi adalah kemauan masyarakat untuk mendukung secara mutlak program-program yang dirancang dan ditentukan tujuannya oleh pemerintah. Pengertian tersebut menimbulkan kesan bahwa ada subordinasi dalam suatu sistem, dimana perencana pembangunan yang dalam hal ini adalah pemerintah menjadi pihak yang menempati hirearki tertinggi dan masyarakat merupakan pihak yang menempati hirearki terendah. Hal ini menyebabkan adanya eksploitasi terhadap masyarakat dalam pelaksanaan pembangunan. Castillo (1983) dalam Sadly (2004) menyatakan bahwa partisipasi adalah suatu pendekatan untuk pembangunan dengan melibatkan masyarakat untuk memperbaiki kehidupannya melalui pembangunan.

Sedangkan Arnstein (1969) dalam Sahawi (2016) partisipasi adalah sebagai kekuatan yang dimiliki oleh masyarakat untuk mengatasi persoalannya pada masa kini guna mencapai kehidupan yang lebih baik pada masa mendatang. Dijelaskan bahwa partisipasi merupakan redistribusi kekuatan yang memungkinkan kaum terpinggirkan secara ekonomi dan politik untuk dilibatkan dalam perencanaan pembangunan masa depan. Makna partisipasi yang mengacu pada pendapat Arnstein adalah kekuatan yang dimiliki oleh masyarakat untuk mengatasi persoalannya pada masa kini guna mencapai kehidupan yang lebih baik pada masa mendatang. Nasdian (2014) mendefinisikan partisipasi sebagai proses aktif, inisiatif diambil oleh warga komunitas sendiri, dibimbing oleh cara berfikir mereka sendiri, dengan menggunakan sarana dan proses (lembaga dan mekanisme) dimana mereka dapat menegaskan kontrol secara efektif. Titik tolak dari partisipasi adalah memutuskan, bertindak, kemudian mereka merefleksikan tindakan tersebut sebagai subjek yang sadar. 


\section{Faktor-Faktor yang Memengaruhi Partisipasi}

Menurut Nasution (2009) dalam Purnamasari dan Ma'ruf (2016), faktor-faktor yang mempengaruhi partisipasi masyarakat sebagai berikut: (a) Komunikasi: Komunikasi merupakan suatu proses penyampaian informasi dari satu orang ke orang lainnya. Interaksi dan komunikasi sering dilakukan masyarakat agar dapat menambah informasi baru yang belum mereka ketahui terkait dengan pelaksanaan program pembangunan. Komunikasi yang intens juga akan mengakrabkan masyarakat serta membuat mereka merasakan manfaat dari program pembangunan tersebut. Manfaat program yang mereka peroleh karena terjalinnya komunikasi yang baik dapat mendorong mereka untuk meningkatkan partisipasi; (b) Tingkat Pendidikan: Pendidikan yang dimiliki oleh masyarakat menjadi salah satu faktor penting yang mendasari masyarakat untuk berpartisipasi. Seperti tercantum dalam penelitian Abdulmalik, Oyinbo, dan Sami (2013), semakin tinggi pendidikan maka semakin tinggi pula partisipasi; (c) Pekerjaan (Mata Pencaharian): Pekerjaan dapat dilihat berdasarkan jenis pekerjaan dan pendapatan yang diperolehnya. Besarnya pendapatan memberi peluang bagi masyarakat untuk berpartisipasi, karena penghasilan mempengaruhi kemampuan finansial masyarakat. Masyarakat yang memiliki kemampuan finansial baik akan bersedia untuk berpartisipasi dalam mensukseskan pembangunan (Nasution 2009 dalam Purnamasari dan Ma'ruf 2016); (d) Usia: Faktor usia merupakan salah satu faktor yang mempengaruhi sikap seseorang terhadap kegiatan-kegiatan kemasyarakatan yang ada. Mereka dari kelompok usia menengah ke atas dengan keterikatan moral kepada nilai dan norma masyarakat yang lebih mantap cenderung lebih banyak berpartisipasi dari pada yang dari kelompok sebaliknya. Penelitian Abdulmalik, Oyinbo, dan Sami (2013) menunjukkan bahwa usia berpengaruh terhadap partisipasi seseorang; dan (e) Lama Tinggal: Lamanya tinggal seseorang dalam lingkungan tertentu dan pengalamannya berinteraksi dengan lingkungan tersebut akan berpengaruh pada partisipasi seseorang. Nasution (2009) dalam Purnamasari dan Ma'ruf (2016) berpendapat bahwa semakin lama seseorang tinggal di lingkungannya, maka rasa memiliki terhadap lingkungan cenderung lebih terlihat dalam partisipasinya yang besar dalam setiap kegiatan lingkungan tersebut. Hal tersebut selaras dengan pernyataan Wijaksono (2013) dalam penelitiannya yang menyebutkan semakin lama seseorang tinggal dan menetap di suatu daerah pada umunya akan memberikan pengaruh positif bagi perkembangan kehidupan psikologisnya. Sehingga dapat merangsang rasa memiliki yang mendalam yang pada akhirnya tumbuh kesadaran untuk memelihara, mengelola dan mengembangkan hasil pembangunan berupa perbaikan prasarana dan fasilitas yang ada.

\section{Solidaritas Sosial}

Mengadu nasib menjadi nelayan tentu merupakan pekerjaan yang sangat beresiko. Banyak hal yang dapat mengancam jiwa nelayan saat sedang melaut, seperti bersentuhan langsung dengan gelombang air laut yang tidak menentu, badai samudera, serangan hewan liar dan banyak kejadian-kejadian yang dapat merugikan lainnya. Oleh karena itu, pekerjaan seorang nelayan sudah seharusnya mendapatkan perhatian lebih dari pemerintah Indonesia untuk diberikan sebuah jaminan perlindungan.

Berdasarkan Undang-undang Republik Indonesia No. 40 Tahun 2014 dalam Thaibah (2015), asuransi adalah perjanjian antara dua belah pihak, yaitu perusahaan asuransi dan pemegang polis, yang menjadi dasar bagi penerimaan premi oleh perusahaan asuransi sebagai imbalan untuk: (a) memberikan penggantian kepada tertanggung atau pemegang polis karena kerugian, kerusakan, biaya yang timbul, kehilangan keuntungan, atau tanggung jawab hukum kepada pihak ketiga yang mungkin diderita tertanggung atau pemegang polis karena terjadinya suatu peristiwa yang tidak pasti; atau (b) memberikan pembayaran yang didasarkan pada meninggalnya tertanggung atau pembayaran yang didasarkan pada hidupnya tertanggung dengan manfaat yang besarnya telah ditetapkan dan/atau didasarkan pada hasil pengelolaan dana; (c) Pemerintah melalui Kementerian Kelautan dan Perikanan (KKP) berupaya untuk menjalankan Undang-Undang Republik Indonesia Nomor 7 Tahun 2016 tentang Perlindungan dan Pemberdayaan Nelayan, Pembudidaya Ikan dan Petambak Garam, yaitu: (d) bahwa Pancasila dan Undang-Undang Dasar Negara Republik Indonesia Tahun 1945 mengamanatkan negara mempunyai tanggung jawab untuk melindungi segenap bangsa Indonesia dan seluruh tumpah darah Indonesia dan untuk memajukan kesejahteraan umum, mencerdaskan kehidupan bangsa, serta mewujudkan keadilan sosial bagi seluruh rakyat Indonesia; (e) bahwa untuk mewujudkan tujuan bernegara menyejahterakan 
rakyat, termasuk Nelayan, Pembudi Daya Ikan, dan Petambak Garam, negara menyelenggarakan Perlindungan dan Pemberdayaan Nelayan, Pembudi Daya Ikan, dan Petambak Garam secara terencana, terarah, dan berkelanjutan; (e) bahwa Nelayan, Pembudi Daya Ikan, dan Petambak Garam sangat tergantung pada sumber daya Ikan, kondisi lingkungan, sarana dan prasarana, kepastian usaha, akses permodalan, ilmu pengetahuan, teknologi, dan informasi sehingga membutuhkan perlindungan dan pemberdayaan; (f) bahwa peraturan perundang-undangan yang mengatur mengenai Perlindungan dan Pemberdayaan Nelayan,Pembudi Daya Ikan, dan Petambak Garam belum komprehensif; dan (g) bahwa berdasarkan pertimbangan sebagaimana dimaksud dalam huruf a, huruf $b$, huruf $c$, dan huruf d perlu membentuk Undang-Undang tentang Perlindungan dan Pemberdayaan Nelayan, Pembudi Daya Ikan, dan Petambak Garam;

Undang-undang tersebut lantas menjadi sebuah regulasi yang secara jelas mengatur tentang perlindungan hukum bagi nelayan yang ada di Indonesia agar terhindar dari kerugian yang mungkin dialaminya yang diakibatkan dari resiko pekerjaanya. Dengan lahirnya Undang-Undang Nomor 7 Tahun 2016 Tentang Perlindungan dan Pemberdayaan Nelayan, Pembudi Daya Ikan, dan Petambak Garam, diharapkan bahwa tujuan negara untuk menyejahterakan rakyatnya dapat terwujud. Rani (2016) menyebutkan bahwa Pasal 3 Undang-Undang Nomor 7 Tahun 2016 menentukan bahwa tujuan dibentuknya Undang-Undang ini adalah: (1) Menyediakan prasarana dan sarana yang dibutuhkan dalam mengembangkan usaha; (2) Memberikan kepastian usaha yang berkelanjutan; (3) Meningkatkan kemampuan dan kapasitas Nelayan, Pembudi Daya Ikan, dan Petambak Garam; (4) Menguatkan kelembagaan dalam mengelola sumber daya Ikan dan sumber daya kelautan serta dalam menjalankan usaha yang mandiri, produktif, maju, modern, dan berkelanjutan; dan mengembangkan prinsip kelestarian lingkungan; (5) Menumbuhkembangkan sistem dan kelembagaan pembiayaan yang melayani kepentingan usaha; (6) Melindungi dari risiko bencana alam, perubahan iklim, serta pencemaran; dan (7) Memberikan jaminan keamanan dan keselaatan serta bantuan hukum.

Berdasarkan ketentuan di atas, bahwa Udang-Udang mengamanatkan bahwa negara berkewajiban memberikan jaminan kesejahteraan bagi nelayan dengan berbagai aspek perlindungan, baik secara ekonomi, keamanan, keselamatan, maupun secara kepastian hukum.

\section{PENDEKATAN LAPANG}

\section{Pendekatan dan Metode Penelitian}

Pendekatan penelitian yang digunakan adalah pendekatan kuantitatif yang didukung dengan data kualitatif. Pendekatan kuantitatif dilakukan dengan metode survei. Data kualitatif digunakan peneliti dengan melakukan wawancara mendalam kepada informan menggunakan panduan pertanyaan yang akan dituliskan dalam catatan harian. Informasi yang didapatkan dari hasil wawancara ini akan dibentuk menjadi suatu narasi yang digunakan untuk menjelaskan dan melengkapi data yang diperoleh dari kuesioner, baik secara keseluruhan, maupun pada setiap sub bagian hasil laporan.

\section{Lokasi dan Waktu Penelitian}

Waktu penelitian dilaksanakan pada tanggal 11-21 April 2019. Waktu penelitian yang dimaksud mencakup waktu selama pembuatan proposal peneliti intensif berada di wilayah penelitian sampai peneliti memberbanyak laporan penelitian. Selama pengambilan data berlangsung, peneliti tinggal bersama subjek penelitian di lapangan dalam jangka waktu yang telah ditetapkan. Hal ini dilakukan agar peneliti dapat mengetahui lokasi penelitian dengan baik dan juga terciptanya hubungan sosial yang dekat dengan subjek penelitian. Kegiatan penelitian meliputi penyusunan proposal dan instrumen penelitian, kolokium, pengumpulan data di lapangan, pengolahan dan analisis data, penulisan draft skripsi, sidang skripsi, dan perbaikan skripsi.

\section{Teknik Pengolahan dan Analisis Data}

Populasi ialah jumlah keselurahan dari unit analisa yang akan di teliti. Populasi dalam penelitian ini adalah masyarakat nelayan yang mengikuti program asuransi nelayan yang ada di Pulau Harapan, Kecamatan Kepulauan Seribu Utara, Provinsi DKI Jakarta. Unit analisis dalam penelitian ini adalah 
individu nelayan di Pulau Harapan. Subjek dalam penelitian ini adalah responden dan informan. Responden adalah individu yang memberikan informasi tentang dirinya sedangkan informan adalah pihak yang dapat memberikan informasi maupun keterangan tambahan berkaitan dengan penelitian yang dilakukan. Dengan demikian teknik pengambilan responden dalam penelitian ini yaitu simple random sampling, yakni sebuah sample yang diambil sedemikian rupa sehingga tiap unit penelitian atau satuan elementer dari populasi mempunyai kesempatan yang sama untuk dipilih sebagai sampel (Singarimbun 1989). Teknik ini dipilih karena responden yang menjadi sasaran bersifat homogen yaitu nelayan yang terdaftar dalam program asuransi nelayan. Jumlah sampel keseluruhan yang akan diambil adalah sebanyak 45 responden yang dituangkan ke dalam kerangka sampling.

Sementara itu, Teknik penentuan informan dengan cara purposive (sengaja) yang jumlahnya tidak dibatasi. Penetapan informan dilakukan dengan menggunakan teknik bola salju (snow ball) untuk memperoleh data dan informasi dari satu informan ke informan lainnya. Pencarian informan akan berhenti bilamana tambahan informasi tidak lagi menghasilkan pengetahuan baru atau sudah berada pada titik jenuh. Adapun pihak-pihak yang dijadikan informan adalah aparatur di pulau dan tokoh masyarakat setempat, yang dianggap mengetahui terkait asuransi nelayan.

Penelitian ini mempunyai dua jenis data yang akan diolah dan dianalisis yaitu data kuantitaif dan data kualitatif. Data kuantitatif menggunakan aplikasi Microsoft Excel 2013 dan SPSS Version 24.0 Data yang diperoleh dari hasil kuesioner dimasukkan ke dalam Microsoft Excel 2013 untuk selanjutnya dilakukan proses pengkodean berdasarkan tingkatan ordinal yang sudah dibuat pada definisi operasional. Kemudian dilakukan analisis data dengan uji statistik non-parametrik Rank Spearman.

\section{GAMBARAN UMUM LOKASI}

\section{Gambaran Umum Desa Kiarapandak}

Pulau Harapan Kepulauan Seribu termasuk kedalam wilayah Kota Madya Jakarta Utara Provinsi DKI Jakarta. Pulau Harapan juga termasuk salah satu dari enam kelurahan yang ada di Kabupaten Administrasi Kepulauan Seribu dengan luas daratan 244.72 ha dan membawahi 30 Pulau. Pulau Harapan memiliki luas lahan sebesar 6.70 ha. Pulau Harapan menjadi salah satu pulau yang berpenduduk di Kepulauan Seribu, dengan jumlah penduduk 2359 yang terdiri dari laki-laki 1.154 dan perempuan 1.205. Sebanyak $51.1 \%$ penduduk tidak bersekolah dan hanya sampai lulus SD/sederajat. Sebanyak $12.5 \%$ bermata pencaharian sebagai nelayan.

\section{Asuransi di Pulau Harapan}

Pulau Harapan termasuk salah satu tempat yang menjadi sasaran dijlankannya program asuransi nelayan. Pertama kali di jalankan pada awal tahun 2017. Menurut Sudin (pendamping pulau) Pulau Harapan, Pak Momo, para nelayan cukup antusias untuk mengikuti asuransi yang diselenggrakan pihak KKP dengan Jasindo. Perserta terdaftar dari Kelurahan Pulau Harapan yaitu 207 orang nelayan, 127 orang dari Pulau Harapan dan 80 orang dari Pulau Sabira.

Syarat untuk bisa terdaftar cukup mudah, nelayan hanya disuruh untuk mengumpulkan KTP dan Kartu Nelayan. KTP digunakan untuk identitas serta untuk mengetahui usia nelayan, karena usia maksimal untuk mengikuti program adalah 63 tahun. Usia maksimal 63 tahun karena usia 63 adalah batas maksimal usia produktif seseorang. Selanjutnya, Kartu Nelayan digunakan sebagai identitas bahwa pemegang kartu benar-benar seorang nelayan. Namun, mulai tahun 2019, penggunaan Kartu Nelayan digantikan dengan Kartu Kusuka, yang fungsinya sebagai database tunggal pelaku usaha kelautan dan perikanan yang dimanfaatkan kementerian untuk menentukan kebijakan terkait program perlindungan dan pemberdayaan pelaku usaha kelautan dan perikanan.

Kendala utama dalam proses berlangsungnya program, terutama di Pulau Harapan yaitu latar belakang pendidikan. Mayoritas nelayan bahkan penduduk Pulau Harapan berlatar belakang Pendidikan yang rendah, sehingga menyebabkan pemahaman terhadap syarat dan ketentuan tentang program berbeda- 
beda. Hal yang paling sering terjadi, mereka berpikiran bahwa setelah mendapat kartu asuransi, lalu bias berlaku untuk selamanya.

\section{HASIL DAN PEMBAHASAN}

\section{HUBUNGAN FAKTOR INTERNAL DENGAN BENTUK PARTISIPASI NELAYAN DALAM PROGRAM ASURANSI NELAYAN}

Karakteristik yang diuji dengan uji statistik adalah tingkat pendapatan, tingkat pendidikan, usia dan tingkat lama tinggal. Jenis kelamin $100 \%$ laki-laki, karena syarat untuk mengikuti program adalah lakilaki.

\section{Hubungan Tingkat Pendapatan dengan Bentuk Partisipasi}

Pendapatan responden adalah salah satu variabel dari karakteristik individu yang dapat menjadi faktor pendorong dan faktor penghambat partisipasi masyarakat dalam sebuah kegiatan. Berikut di bawah ini adalah tabulasi silang dan hasil uji korelasi tingkat pendapatan dengan tingkat bentuk partisipasi. 
Tabel 1 Tabulasi silang tingkat pendapatan dengan tingkat kehadiran

\begin{tabular}{llcll}
\hline \multirow{2}{*}{$\begin{array}{l}\text { Tingkat } \\
\text { Pendapatan }\end{array}$} & Rendah & Tingkat Kehadiran & Total \\
\cline { 2 - 4 } & $\mathrm{n}(\%)$ & $\mathrm{n}(\%)$ & Tinggi \\
$\mathrm{n}(\%)$ & $\mathrm{n}(\%)$ \\
\hline Rendah & $0(0.0)$ & $5(41.7)$ & $7(58.3)$ & $13(100)$ \\
Sedang & $0(0.0)$ & $10(38.9)$ & $\begin{array}{l}17 \\
(61.1)\end{array}$ & $27(100)$ \\
Tinggi & $0(0.0)$ & $1(16.7)$ & $5(83.3)$ & $6(100)$ \\
Total & $0(0.0)$ & $16(35.6)$ & $\begin{array}{l}\text { 29 } \\
(64.3)\end{array}$ & $45(100)$ \\
\hline
\end{tabular}

Sementara itu, dapat dilihat pada Tabel 1 bahwa partisipasi tinggi didominasi oleh nelayan yang berpenghasilan sedang, berjumlah 27 orang. Responden yang berpenghasilan rendah memiliki tingkat partisipasi yang tinggi pada kategori tingkat kehadiran walaupun hanya satu orang. Responden yang partisipasinya tergolong tinggi adalah mereka yang memiliki penghasilan yang tergolong tinggi dengan jumlah 6 orang. Uji korelasi dilakukan dengan menghubungkan tingkat pendapatan dengan bentuk partisipasi pada tingkat kehadiran. Hasil uji korelasi uji ini memberikan kesimpulan hipotesis bahwa terdapat hubungan antara tingkat pendapatan dengan bentuk partisipasi pada tingkat kehadiran ditolak. Fakta di lapangan menunjukkan bahwa berapapun pendapatan yang didapat nelayan tidak mempengaruhi apakah nelayan tersebut ikut hadir pada kegiatan tentang program.

Tabel 2

Tabulasi silang tingkat pendapatan dengan tingkat kesediaan bekerja sama

\begin{tabular}{lllll}
\hline \multirow{2}{*}{$\begin{array}{l}\text { Tingkat } \\
\text { Pendapatan }\end{array}$} & \multicolumn{3}{c}{ Tingkat Kesediaan Bekerja Sama } & Total \\
\cline { 2 - 5 } & Rendah & Sedang & Tinggi & $\mathrm{n}(\%)$ \\
\hline Rendah & $0(0.0)$ & $1(8.3)$ & $11(91.6)$ & $12(100)$ \\
Sedang & $0(0.0)$ & $8(47.0)$ & $9(53.0)$ & $27(100)$ \\
Tinggi & $0(0.0)$ & $9(69.0)$ & $4(31.0)$ & $6(100)$ \\
\hline Total & $0(0.0)$ & $11(24.4)$ & $34(74.6)$ & $45(100)$ \\
\hline
\end{tabular}

Pada kategori tingkat kesediaan bekerja sama, tingkat partisipasi tinggi masih didominasi oleh nelayan dengan pendapatan sedang yang berjumlah 27 orang atau 75 persen dari responden berpendapatan sedang. Uji korelasi dilakukan dengan menghubungkan tingkat pendapatan dengan bentuk partisipasi tingkat kesediaan bekerja sama. Hasil korelasi pada tabel 19 menunjukkan tidak adanya hubungan yang signifikan antar variabel. Nilai Sig. (2-tailed) menunjukkan angka 0.837 , berarti lebih besar dari 0.05 . Angka koefisien korelasi hasil pengujian adalah -0.32 yang berarti tidak ada hubungan antara dua variabel. 
Tabel 3 Tabulasi silang tingkat pendapatan dengan tingkat kesediaan menggerakkan partisipasi anggota yang lain

\begin{tabular}{|c|c|c|c|c|}
\hline \multirow{2}{*}{$\begin{array}{l}\text { Tingkat } \\
\text { Pendapatan }\end{array}$} & \multicolumn{3}{|c|}{$\begin{array}{c}\text { Tingkat Kesediaan Menggerakkan Partisipasi } \\
\text { Anggota Yang Lain }\end{array}$} & \multirow{2}{*}{$\begin{array}{l}\text { Total } \\
\mathrm{n}(\%)\end{array}$} \\
\hline & $\begin{array}{l}\text { Rendah } \\
\text { n }(\%)\end{array}$ & $\begin{array}{l}\text { Sedang } \\
\mathrm{n}(\%)\end{array}$ & $\begin{array}{l}\text { Tinggi } \\
\mathrm{n}(\%)\end{array}$ & \\
\hline Rendah & $0(0.0)$ & $2(16.7)$ & $\begin{array}{l}10 \\
(83.3)\end{array}$ & $\begin{array}{l}12 \\
(100)\end{array}$ \\
\hline Sedang & $0(0.0)$ & $8(29.6)$ & $\begin{array}{l}19 \\
(70.4)\end{array}$ & $\begin{array}{l}27 \\
(100)\end{array}$ \\
\hline Tinggi & $0(0.0)$ & $1(16.7)$ & $5(83.3)$ & $6(100)$ \\
\hline Total & $0(0.0)$ & 11 & 34 & $\begin{array}{l}45 \\
(100)\end{array}$ \\
\hline
\end{tabular}

Uji korelasi dilakukan dengan menghubungkan tingkat pendapatan dengan bentuk partisipasi tingkat keterlibatan menggerakkan partisipasi anggota yang lain. Hasil uji korelasi menunjukkan bahwa kedua variabel tidak memiliki hubungan yang signifikan dengan koefisien korelasi bernilai 0.95 , sedangkan nilai Sig. (2-tailed) menunjukkan angka 0.537. Hasil uji tersebut memberikan kesimpulan bahwa hipotesis terdapat hubungan antara tingkat pendapatan dengan tingkat keterlibatan menggerakkan partisipasi anggota yang lain ditolak.

\section{Hubungan Tingkat Pendidikan dengan Bentuk Partisipasi}

Pendidikan responden adalah salah satu variabel dari karakteristik individu yang dapat menjadi faktor pendorong dan faktor penghambat partisipasi masyarakat dalam sebuah kegiatan. Semakin tinggi pendidikan yang ditempuh, diharapkan orang tersebut dapat memberikan kontribusi lebih ke masyarakat. Berikut di bawah ini adalah tabulasi silang dan hasil uji korelasi tingkat pendidikan dengan tingkat bentuk partisipasi.

Tabel 4 Tabulasi silang tingkat pendidikan dengan tingkat kehadiran

\begin{tabular}{lllll}
\hline \multirow{2}{*}{$\begin{array}{l}\text { Tingkat } \\
\text { Pendidikan }\end{array}$} & Rendah & Sedang & Tinggi & Total \\
\cline { 2 - 4 } & $\mathrm{n}(\%)$ & $\mathrm{n}(\%)$ & $\mathrm{n}(\%)$ & $\mathrm{n}(\%)$ \\
\hline Rendah & $0(0.0)$ & $4(17.4)$ & $\begin{array}{l}19 \\
(82.6)\end{array}$ & $23(100)$ \\
Sedang & $0(0.0)$ & $10(66.7)$ & $\begin{array}{l}5 \\
(33.3)\end{array}$ & $15(100)$ \\
Tinggi & $0(0.0)$ & $2(28.6)$ & $\begin{array}{l}5 \\
(71.4)\end{array}$ & $7(100)$ \\
\hline Total & $0(0.0)$ & $16(35.6)$ & $\begin{array}{l}29 \\
(64.4)\end{array}$ & $45(100)$ \\
\hline
\end{tabular}

Uji korelasi dilakukun dengan menghubungkan tingkat pendidikan dengan tingkat kehadiran. Hasil uji korelasi menunjukkan bahwa kedua variabel tidak memiliki hubungan yang yang signifikan, dengan nilai koefisien korelasi -0.291. Nilai Sig. (2-tailed) sebesar 0.52, karena nilai Sig. (2-tailed) $0.52>0.05$ berarti tidak ada hubungan yang signifikan antara variabel tingkat pendidikan dan tingkat kehadiran. 
Hasil uji tersebut memberikan kesimpulan bahwa hipotesis terdapat hubungan antara tingkat pendidikan dengan tingkat kehadiran ditolak.

Tabel 5 Tabulasi silang tingkat pendidikan dengan tingkat kesediaan bekerja sama

\begin{tabular}{|c|c|c|c|c|}
\hline \multirow[b]{2}{*}{$\begin{array}{l}\text { Tingkat } \\
\text { Pendidikan }\end{array}$} & \multicolumn{3}{|c|}{ Tingkat Kesediaan Bekerja Sama } & \multirow{2}{*}{$\begin{array}{l}\text { Total } \\
\text { n (\%) }\end{array}$} \\
\hline & $\begin{array}{l}\text { Rendah } \\
\mathrm{n}(\%)\end{array}$ & $\begin{array}{l}\text { Sedang } \\
\mathrm{n}(\%)\end{array}$ & $\begin{array}{l}\text { Tinggi } \\
\mathrm{n}(\%)\end{array}$ & \\
\hline Rendah & $0(0.0)$ & $2(8.7)$ & $\begin{array}{l}21 \\
(91.3)\end{array}$ & $23(100)$ \\
\hline Sedang & $0(0.0)$ & $\begin{array}{l}5 \\
(33.3)\end{array}$ & $\begin{array}{l}10 \\
(66.7)\end{array}$ & $15(100)$ \\
\hline Tinggi & $0(0.0)$ & $\begin{array}{l}4 \\
(57.1)\end{array}$ & $\begin{array}{l}3 \\
(42.9)\end{array}$ & 7 (100) \\
\hline Total & $0(0.0)$ & $\begin{array}{l}11 \\
(24.4)\end{array}$ & $\begin{array}{l}34 \\
(75.6)\end{array}$ & 45 (100) \\
\hline
\end{tabular}

Uji korelasi dilakukan dengan menghubungkan dua variabel tingkat pendidikan dengan tingkat kesediaan bekerja sama. Hasil uji menunjukkan nilai Sig. (2-tailed) sebesar 0.05, yang berarti terdapat hubungan yang signifikan antara kedua variabel. Angka koefisien korelasi menunjukkan nilai sebesar 0.412. Angka koefisien tersebut mengartikan hubungan yang cukup kuat antara kedua variabel yang diuji. Koefisien korelasi yang bernilai negatif berarti terdapat hubungan yang tidak searah, artinya semakin rendah tingkat pendidikan, maka akan semakin tinggi partisipasi tingkat kesediaan bekerja samanya. Berdasarkan hasil uji tersebut, memberikan kesimpulan bahwa hipotesis terdapat hubungan antara tingkat pendidikan dengan tingkat kesediaan bekerja sama diterima.

Tabel 6 Tabulasi silang tingkat pendidikan dengan tingkat kesediaan menggerakkan partisipasi anggota yang lain

\begin{tabular}{lllll}
\hline \multirow{2}{*}{$\begin{array}{l}\text { Tingkat } \\
\text { Pendidikan }\end{array}$} & \multicolumn{2}{c}{$\begin{array}{r}\text { Tingkat Kesediaan Menggerakkan } \\
\text { Partisipasi Anggota Yang Lain }\end{array}$} & Total \\
\cline { 2 - 5 } & $\begin{array}{l}\text { Rendah } \\
\mathrm{n}(\%)\end{array}$ & $\begin{array}{l}\text { Sedang } \\
\mathrm{n}(\%)\end{array}$ & $\begin{array}{l}\text { Tinggi } \\
\mathrm{n}(\%)\end{array}$ & $\mathrm{n}(\%)$ \\
\hline \multirow{2}{*}{ Rendah } & $0(0.0)$ & $1(4.3)$ & $\begin{array}{l}22 \\
(95.7)\end{array}$ & $23(100)$ \\
Sedang & $0(0.0)$ & $\begin{array}{l}9 \\
(60.0)\end{array}$ & $\begin{array}{l}6 \\
(40.0)\end{array}$ & $15(100)$ \\
Tinggi & $0(0.0)$ & $\begin{array}{l}1 \\
(14.3)\end{array}$ & $\begin{array}{l}6 \\
(85.7)\end{array}$ & $7(100)$ \\
\hline \multirow{2}{*}{ Total } & $0(0.0)$ & $\begin{array}{l}11 \\
(24.4)\end{array}$ & $\begin{array}{l}34 \\
(75.6)\end{array}$ & $45(100)$ \\
\hline
\end{tabular}

Uji korelasi dilakukan dengan menghubungkan dua variabel, tingkat pendidikan dengan tingkat keterlibatan menggerakkan partisipasi anggota yang lain. Hasil uji korelasi menunjukkan nilai Sig. (2tailed) 0.018. karena nilai Sig. (2-tailed) 0.018 lebih kecil dari 0.05, maka terdapat hubungan yang signifikan antara kedua variabel. Nilai koefisien korelasi menunjukkan angka -0.35. Angka koefisien korelasi tersebut menunjukkan hubungan yang lemah antara kedua variabel. Sedangkan nilai negatif 
menunjukkan bahwa terjadi hubungan yang tidak searah, artinya semakin rendah tingkat pendidikan, maka akan semakin tinggi keterlibatannya dalam menggerakkan anggota yang lain. Berdasarkan hasil uji tersebut, disimpulkan bahwa hipotesis terdapat hubungan antara tingkat pendidikan dengan tingkat keterlibatan menggerakkan partisipasi anggota yang lain diterima.

\section{Hubungan Tingkat Usia dengan Bentuk Partisipasi}

Usia merupakan salah satu variabel bebas yang menentukan partisipasi nelayan dalam program asuransi nelayan. Menurut BPS (2015) usia produktif berkisar antara 15-64 tahun, sedangkan usia sebelum dan sesudahnya adalah usia tidak produktif yang tergolong beban tanggungan penduduk yang bekerja (usia produktif). Berbeda dengan BPS, di dalam aturan keanggotaan program asuransi nelayan, usia produktif hanya sampai usia 63 tahun.

Tabel 7 Tabulasi silang tingkat usia dengan tingkat kehadiran

\begin{tabular}{|c|c|c|c|c|}
\hline \multirow[b]{2}{*}{$\begin{array}{l}\text { Tingkat } \\
\text { Usia }\end{array}$} & \multicolumn{3}{|c|}{ Tingkat Kehadiran } & \multirow{2}{*}{$\begin{array}{l}\text { Total } \\
\mathrm{n}(\%)\end{array}$} \\
\hline & $\begin{array}{l}\text { Rendah } \\
\mathrm{n}(\%)\end{array}$ & $\begin{array}{l}\text { Sedang } \\
\mathrm{n}(\%)\end{array}$ & $\begin{array}{l}\text { Tinggi } \\
\mathrm{n}(\%)\end{array}$ & \\
\hline Muda & $0(0.0)$ & $\begin{array}{l}2 \\
(50.0)\end{array}$ & $\begin{array}{l}2 \\
(50.0)\end{array}$ & $4(100)$ \\
\hline Dewasa & $0(0.0)$ & $\begin{array}{l}12 \\
(54.5)\end{array}$ & $\begin{array}{l}10 \\
(45.5)\end{array}$ & $22(100)$ \\
\hline Tua & $0(0.0)$ & $\begin{array}{l}2 \\
(10.5)\end{array}$ & $\begin{array}{l}17 \\
(89.5)\end{array}$ & $19(100)$ \\
\hline Total & $0(0.0)$ & $\begin{array}{l}16 \\
(35.6)\end{array}$ & $\begin{array}{l}29 \\
(64.4)\end{array}$ & $45(100)$ \\
\hline
\end{tabular}

Uji korelasi dilakukan dengan menghubungkan antara variabel tingkat usia dengan tingkat kehadiran. Hasil uji korelasi menunjukkan nilai Sig. (2-tailed) sebesar 0.04, yang berarti terdapat hubungan yang signifikan antar dua variabel. Nilai koefisien korelasi menunjukkan angka 0.418 , berarti menunjukkan adanya hubungan yang lemah dan searah dari kedua variabel. Jadi, semakin tinggi usia seseorang, maka akan semakin tinggi pula kehadirannya. Berdasarkan hasil uji yang dilakukan, dapat disimpulkan bahwa hipotesis terdapat hubungan antara tingkat usia dengan tingkat kehadiran dapat diterima.

Tabel 8 Tabulasi silang tingkat usia dengan tingkat kesediaan bekerja sama

\begin{tabular}{|c|c|c|c|c|}
\hline \multirow[b]{2}{*}{$\begin{array}{l}\text { Tingkat } \\
\text { Usia }\end{array}$} & \multicolumn{3}{|c|}{ Tingkat Kesediaan Bekerja Sama } & \multirow{2}{*}{$\begin{array}{l}\text { Total } \\
\mathrm{n}(\%)\end{array}$} \\
\hline & $\begin{array}{l}\text { Rendah } \\
\text { n (\%) }\end{array}$ & $\begin{array}{l}\text { Sedang } \\
\mathrm{n}(\%)\end{array}$ & $\begin{array}{l}\text { Tinggi } \\
\mathrm{n}(\%)\end{array}$ & \\
\hline Muda & $0(0.0)$ & $\begin{array}{l}2 \\
(50.0)\end{array}$ & $\begin{array}{l}2 \\
(50.0)\end{array}$ & $4(100)$ \\
\hline Dewasa & $0(0.0)$ & $\begin{array}{l}7 \\
(31.8)\end{array}$ & $\begin{array}{l}15 \\
(68.2)\end{array}$ & $22(100)$ \\
\hline Tua & $0(0.0)$ & $\begin{array}{l}2 \\
(10.5)\end{array}$ & $\begin{array}{l}17 \\
(89.5)\end{array}$ & $19(100)$ \\
\hline Total & $0(0.0)$ & $\begin{array}{l}11 \\
(24.4)\end{array}$ & $\begin{array}{l}34 \\
(75.6)\end{array}$ & $45(100)$ \\
\hline
\end{tabular}


Uji korelasi dilakukan dengan menghubungkan tingkat usia dengan tingkat kesediaan bekerja sama. Hasil uji korelasi menunjukkan bahwa terdapat hubungan yang signifikan antara kedua variabel karena memiliki nilai Sig. (2-tailed) lebih kecil dari 0.05. nilai koefisien korelasi menunjukkan angka 0.299, yang berarti hubungan yang terjadi antar kedua variabel bersifat lemah namun searah. Berdasarkan hasil uji yang telah dilakukan, dapat diambil kesimpulan bahwa hipotesis terdapat hubungan antara tingkat usia dengan tingkat kesediaan bekerja sama diterima.

Tabel 9 Tabulasi silang tingkat usia dengan tingkat kesediaan menggerakkan partisipasi anggota yang lain

\begin{tabular}{|c|c|c|c|c|}
\hline \multirow{2}{*}{$\begin{array}{l}\text { Tingkat } \\
\text { Usia }\end{array}$} & \multicolumn{3}{|c|}{$\begin{array}{l}\text { Tingkat Kesediaan Menggerakkan } \\
\text { Partisipasi Anggota Yang Lain }\end{array}$} & \multirow{2}{*}{$\begin{array}{l}\text { Total } \\
\mathrm{n}(\%)\end{array}$} \\
\hline & $\begin{array}{l}\text { Rendah } \\
\mathrm{n}(\%)\end{array}$ & $\begin{array}{l}\text { Sedang } \\
\mathrm{n}(\%)\end{array}$ & $\begin{array}{l}\text { Tinggi } \\
\text { n }(\%)\end{array}$ & \\
\hline Muda & $0(0.0)$ & $0(0.0)$ & $\begin{array}{l}4 \\
(100.0)\end{array}$ & $4(100)$ \\
\hline Dewasa & $0(0.0)$ & $\begin{array}{l}10 \\
(45.5)\end{array}$ & $\begin{array}{l}12 \\
(54.5)\end{array}$ & $22(100)$ \\
\hline Tua & $0(0.0)$ & $1(5.3)$ & $\begin{array}{l}18 \\
(94.7)\end{array}$ & 19 (100) \\
\hline Total & $0(0.0)$ & $\begin{array}{l}11 \\
(24.4)\end{array}$ & $\begin{array}{l}34 \\
(75.6)\end{array}$ & 45 (100) \\
\hline
\end{tabular}

Uji korelasi dilakukan dengan menghubungkan tingkat usia dengan tingkat keterlibatan menggerakkan partisipasi anggota yang lain. Hasil uji korelasi menunjukkan bahwa tidak ada hubungan yang signifikan antara kedua variabel karena nilai Sig. (2-tailed) adalah 0.068 dan lebih besar dari 0.05. Berdasarkan hasil uji yang telah dilakukan, dapat diambil kesimpulan bahwa hipotesis terdapat hubungan antara tingkat usia dengan tingkat keterlibatan menggerakkan partisipasi anggota yang lain ditolak.

\section{Hubungan Tingkat Lama Tinggal dengan Bentuk Partisipasi}

Lama tinggal dianggap menjadi salah satu faktor pendorong atau penghambat dari partisipasi nelayan dalam program asuransi nelayan. Diharapkan semakin lama responden tinggal di lokasi, maka tingkat partisipasinya akan semakin tinggi. Semakin lama tinggal, maka mereka akan semakin akrab dan mudah berbaur dengan masyarakat sekitar, dengan begitu mereka tidak akan sungkan untuk mengikuti suatu kegiatan bersama dengan masyarakat yang lain. 
Tabel 10 Tabulasi silang tingkat lama tinggal dengan tingkat kehadiran

\begin{tabular}{|c|c|c|c|c|}
\hline \multirow{2}{*}{$\begin{array}{l}\text { Tingkat } \\
\text { Lama } \\
\text { Tinggal }\end{array}$} & \multicolumn{3}{|c|}{ Tingkat Kehadiran } & \multirow{2}{*}{$\begin{array}{l}\text { Total } \\
\mathrm{n}(\%)\end{array}$} \\
\hline & $\begin{array}{l}\text { Rendah } \\
\mathrm{n}(\%)\end{array}$ & $\begin{array}{l}\text { Sedang } \\
\mathrm{n}(\%)\end{array}$ & $\begin{array}{l}\text { Tinggi } \\
\mathrm{n}(\%)\end{array}$ & \\
\hline Rendah & $0(0.0)$ & $\begin{array}{l}3 \\
(42.9)\end{array}$ & $\begin{array}{l}4 \\
(57.1)\end{array}$ & 7 (100) \\
\hline Sedang & $0(0.0)$ & $\begin{array}{l}12 \\
(42.9)\end{array}$ & $\begin{array}{l}16 \\
(57.1)\end{array}$ & $28(100)$ \\
\hline Tinggi & $0(0.0)$ & $\begin{array}{l}1 \\
(10.0)\end{array}$ & $\begin{array}{l}9 \\
(90.0)\end{array}$ & $10(100)$ \\
\hline Total & $0(0.0)$ & $\begin{array}{l}16 \\
(35.6)\end{array}$ & $\begin{array}{l}29 \\
(64.4)\end{array}$ & 45 (100) \\
\hline
\end{tabular}

Uji korelasi dilakukan dengan menghubungkan antara variabel tingkat lama tinggal dengan tingkat kehadiran. Hasil uji korelasi ini menunjukkan bahwa tidak terdapat hubungan yang signifikan karena nilai Sig. (2-tailed) dari uji ini adalah 0.115 lebih besar dari 0.05. Jadi, dari hasil uji tersebut dapat diambil kesimpulan bahwa hipotesis terdapat hubungan antara tingkat lama tinggal dengan tingkat kehadiran ditolak.

Tabel 11 Tabulasi silang tingkat lama tinggal dengan tingkat kesediaan bekerja sama

\begin{tabular}{|c|c|c|c|c|}
\hline \multirow{2}{*}{$\begin{array}{l}\text { Tingkat } \\
\text { Lama } \\
\text { Tinggal }\end{array}$} & \multicolumn{3}{|c|}{ Tingkat Kesediaan Bekerja Sama } & \multirow{2}{*}{$\begin{array}{l}\text { Total } \\
\mathrm{n}(\%)\end{array}$} \\
\hline & $\begin{array}{l}\text { Rendah } \\
\text { n (\%) }\end{array}$ & $\begin{array}{l}\text { Sedang } \\
\mathrm{n}(\%)\end{array}$ & $\begin{array}{l}\text { Tinggi } \\
\mathrm{n}(\%)\end{array}$ & \\
\hline Rendah & $0(0.0)$ & $\begin{array}{l}3 \\
(42.9)\end{array}$ & $\begin{array}{l}4 \\
(57.1)\end{array}$ & $7(100)$ \\
\hline Sedang & $0(0.0)$ & $\begin{array}{l}7 \\
(25.0)\end{array}$ & $\begin{array}{l}21 \\
(75.0)\end{array}$ & $28(100)$ \\
\hline Tinggi & $0(0.0)$ & $\begin{array}{l}1 \\
(10.0)\end{array}$ & $\begin{array}{l}9 \\
(90.0)\end{array}$ & $10(100)$ \\
\hline Total & $0(0.0)$ & $\begin{array}{l}11 \\
(24.4)\end{array}$ & $\begin{array}{l}34 \\
(75.6)\end{array}$ & $45(100)$ \\
\hline
\end{tabular}

Uji korelasi dilakukan dengan menghubungkan antara variabel tingkat lama tinggal dengan tingkat kesediaan bekerja sama. Hajil uji korelasi kedua variabel menunjukkan bahwa tidak ada hubungan yang signifikan dengan nilai Sig. 0.127 lebih besar dari 0.05. Hasil uji tersebut menyimpulkan bahwa hipotesis terdapat hubungan antara tingkat lama tinggal dengan tingkat kesediaan bekerja sama ditolak. 
Tabel 12 Tabulasi silang tingkat lama tinggal dengan tingkat kesediaan menggerakkan partisipasi anggota yang lain

\begin{tabular}{|c|c|c|c|c|}
\hline \multirow{2}{*}{$\begin{array}{l}\text { Tingkat } \\
\text { Lama } \\
\text { Tinggal }\end{array}$} & \multicolumn{3}{|c|}{$\begin{array}{c}\text { Tingkat Kesediaan Menggerakkan Partisipasi } \\
\text { Anggota Yang Lain }\end{array}$} & \multirow{2}{*}{$\begin{array}{l}\text { Total } \\
\text { n (\%) }\end{array}$} \\
\hline & $\begin{array}{l}\text { Rendah } \\
\mathrm{n}(\%)\end{array}$ & $\begin{array}{l}\text { Sedang } \\
\mathrm{n}(\%)\end{array}$ & $\begin{array}{l}\text { Tinggi } \\
\mathrm{n}(\%)\end{array}$ & \\
\hline Rendah & $0(0.0)$ & $2(28.6)$ & $5(71.4)$ & 7 (100) \\
\hline Sedang & $0(0.0)$ & $8(28.6)$ & $\begin{array}{l}20 \\
(71.4)\end{array}$ & $28(100)$ \\
\hline Tinggi & $0(0.0)$ & $1(10.0)$ & $9(90.0)$ & $10(100)$ \\
\hline Total & $0(0.0)$ & $11(24.4)$ & $\begin{array}{l}34 \\
(75.6)\end{array}$ & $45(100)$ \\
\hline
\end{tabular}

Uji korelasi dilakukan dengan menguji variabel tingkat tinggal dengan tingkat keterlibatan menggerakkan partisipasi anggota yang lain. Hasil uji korelasi kedua variabel menunjukkan nilai Sig. (2-tailed) $0.326>0.05$ yang berarti tidak ada hubungan yang signifikan yang terjadi antar kedua variabel. Hasil uji tersebut menyimpulkan bahwa hipotesis terdapat hubungan antara tingkat lama tinggal dengan tingkat keterlibatan menggerakkan partisipasi anggota yang lain ditolak.

\section{ANALISIS VARIABEL YANG BERHUBUNGAN}

\section{Hubungan Tingkat Pendidikan dengan Tingkat Kehadiran}

Terdapat hubungan yang signifikan antara tingkat pendidikan dengan tingkat kehadiran. Angka koefisien korelasi menunjukkan nilai -0.412, artinya terdapat hubungan yang tidak searah antara tingkat pendidikan dengan tingkat kehadiran. Maksudnya, apabila tingkat pendidikan responden semakin tinggi, maka akan mengakibatkan tingkat kehadiran responden dalam program semakin menurun.

Pernyataan ALI (48) menyebutkan bahwa alasan beliau datang ke acara atau rapat yang diselenggarakan program yaitu agar bisa menambah wawasan. Hal ini menunjukkan bahwa beliau mempunyai tingkat pendidikan yang rendah dan mau untuk mengikuti kegiatan demi dirinya sendiri.

\section{Hubungan Tingkat Pendidikan dengan Tingkat Kesediaan Bekerja Sama}

Terdapat hubungan yang signifikan antara tingkat pendidikan dengan tingkat kesediaan bekerja sama. Angka koefisien korelasi menunjukkan nilai -0.350, artinya terdapat hubungan yang signifikan dan tidak searah antara tingkat pendidikan dengan tingkat kesediaan bekerja sama. Apabila tingkat pendidikan responden semakin tinggi, maka akan mengakibatkan berkurangnya tingkat partisipasi dalam kesediaan bekerja sama.

Semakin tinggi pendidikan seseorang, maka seseorang tersebut memiliki ego yang cukup tinggi karena merasa bisa mengerjakan sendiri seperti yang diucapkan salah satu responden yaitu AKH (36). Beliau mengatakan karna bisa sendiri maka tidak akan minta bantuan atau bekerja sama dengan orang lain. Akan tetapi apabila ada yang tidak bisa dan meminta untuk bekerja sama, maka beliau dengan senang hati akan menyetujuinya. Berbeda halnya dengan yang berpendidikan rendah, karena merasa kurang yakin akan kemampuan dirinya, maka ada dorongan untuk bekerja sama agar lebih efektif dalam mengerjakan kegiatan dari program asuransinya.

\section{Hubungan Tingkat Usia dengan Tingkat Kehadiran}

Terdapat hubungan yang cukup signifikan antara tingkat usia dengan tingkat kehadiran. Angka koefisien korelasi menunjukkan nilai 0.418 , yang berarti terdapat hubungan signifikan antara kedua variabel tersebut. Hal itu berarti, semakin tinggi tingkat usia responden maka akan meningkat juga tingkat kehadiran responden dalam kegiatan program. 
Semakin tinggi usia seseorang, maka kecenderungan mereka untuk bersosialisasi atau bertemu teman sebayanya akan lebih tinggi yang mengakibatkan tingkat kehadiran mereka tinggi. Karena dengan mereka turut hadir dalam kegiatan, maka mereka akan mempunyai teman untuk saling berinteraksi.

\section{Hubungan Tingkat Usia dengan Tingkat Kesediaan Bekerja Sama}

Terdapat hubungan yang signifikan antara tingkat usia dengan tingkat kesediaan bekerja sama. Angka koefisien korelasi menunjukkan nilai 0.299, yang berarti terdapat hubungan yang signifikan antara kedua variabel. Hal itu menunjukkan bahwa, apabila tingkat usia tinggi akan mengakibatkan tingginya juga tingkat kesediaan bekerja sama. Hal tersebut didukung dengan pernyataan berikut ini,

Pernyataan MAS (58) menyebutkan memang lebih baik untuk bekerja sama, dikarenakan faktor usia beliau. Semakin tua beliau, maka akan lebih baik jika ada orang yang mengajaknya bekerja sama. Selain meringankan pekerjaannya, juga menjadikan adanya teman untuk berinteraksi.

\section{KESIMPULAN}

Hasil dari penelitian tentang Analisis Partisipasi Nelayan dalam Program Asuransi Nelayan di Pulau Harapan, Kecamatan Kepulauan Seribu Utara, Kabupaten Kepulauan Seribu, Provinsi DKI Jakarta dapat disimpulkan sebagai berikut: (a) Penelitian ini dilakukan bertujuan untuk menganalisis hubungan faktor internal (yang terdiri dari usia, tingkat pendidikan, tingkat pendapatan, dan tingkat lama tinggal) terhadap bentuk partisipasi (yang terdiri dari tingkat kehadiran, tingkat kesediaan bekerja sama, dan tingkat keterlibatan dalam menggerakkan partisiapsi anggota yang lain); (b) Tingkat pendidikan berhubungan dengan tingkat kesediaan bekerja sama dan tingkat menggerakkan partisipasi yang lain, karena semakin tinggi tingkat pendidikan si responden, maka akan semakin tinggi ego yang mereka punya sehingga mereka merasa bisa mengerjakan semuanya sendiri serta tidak mau mengajak orang lain untuk ikut serta; dan (c) Tingkat usia berhubungan dengan tingkat kehadiran serta tingkat kesediaan bekerja sama, karena semakin tua si responden, maka ia akan semakin merasa butuh teman untuk mengobrol. Sehingga mereka akan hadir dalam kegiatan serta mengajak bekerja sama untuk meningkatkan intensitas mereka mengobrol dengan nelayan lain.

\section{Saran}

Saran yang dapat disampaikan sesuai hasil penelitian yang didapatkan pada penelitian ini adalah: (a) Tingkat partisipasi nelayan pada tingkat pendapatan harus ditingkatkan, dengan mengadakan musyawarah guna membahas pentingnya berperan aktif dalam program. Meskipun pendapatan mereka tidak dipengaruhi langsung oleh program, setidaknya masih ada manfaat yang bisa diambil ketika mengikuti program. Hal tersebut juga berguna untuk membantu penyelesaian masalah nelayan ketika terjadinya krisis; (b) Tingkat partisipasi nelayan pada tingkat pendidikan juga harus ditingkatkan, dengan cara memberikan masukan masukan guna memberikan kesadaran bahwa mereka hidup bermasyarakat. Oleh karena itu, dengan menyadari hal tersebut, maka akan meningkatkan tingkat partisipasi ke arah positif; dan (c) Lakukan musyawarah yang dikhususkan guna mencari dan menganalisis kebutuhan nelayan. Hal tersebut berguna untuk meningkatkan kesadaran tentang pentingnya program ini serta meningkatkan kepekaan terhadap sesamanya sehingga akan meningkatkan partisipasi dalam semua aspek. 


\section{DAFTAR PUSTAKA}

Abdulmalik RO, Oyinbo O, dan Sami RA. 2013. Determinants of crop farmers participation in agricultural insurance in the federal capital territory, Abuja, Nigeria. Greener Journalof Agricultural Science. [Internet]. [25 Februari 2018]. Vol. 3(1): 21-26. Dapat diunduh dari http://dx.doi.org/10.15580/GJAS.2013.1.111212255

Adam L. 2015. Telaah Kebijakan Perlindungan Nelayan dan Pembudi Daya Ikan di Indonesia [Internet]. [29 Juli 2018]. Jakarta (ID): Kajian Vol. 20(2):145-162. Dapaat diunduh dari http://www.dpr.go.id/dokakd/dokumen/RJ1-20190425-125010-5297.pdf

[Badan Pusat Statistik]. 2017. Berita resmi statistik[Internet]. [Diunduh 2017 September 2015]. Dapat diunduh dari https://www.bps.go.id/website/brs_ind/brsInd-20170116093952.pdf

[Badan Pusat Statistik]. 2013. Jumlah Rumah Tangga Usaha Penangkapan Ikan Menurut Jenis dan Penangkapan Ikan Tahun 2013. [Internet]. [diunduh 26 Februari 2018]. Dapat diunduh dari http://st2013.bps.go.id/dev2/index.php/site/tabel?tid=59\&wid=0

[Badan Pusat Statistik]. 2017. Statistik Indonesia 2017. Jakarta (ID): BPS.

Mubyarto, et.al. 1984. Nelayan dan Kemiskinan: Studi Ekonomi Antropologi di Desa Pantai. Jakarta, Rajawali.

Nasdian FT. 2014. Pengembangan Masyarakat (Community Development). Institut Pertanian Bogor : Bogor.

Nasution Z. 2009. Solidaritas Sosial dan Partisipasi Masyarakat Desa Transisi (Suatu Tinjauan Sosiologis. Malang (ID): UMM Press

Patriana R. 2011. Pola Adaptasi Nelayan Terhadap Perubahan Iklim (Studi Kasus Nelayan Dusun Ciawitali, Desa Pamotan, Kecamatan Kalipucang, Kabupaten Ciamis, Jawa Barat) [skripsi]. [Internet]. [24 Agustus 2018]. Bogor (ID):Institut Pertanian Bogor. Dapat diunduh dari: https://repository.ipb.ac.id/bitstream/handle/123456789/47453/I11rpa1.pdf?sequence=1\&isAllo wed $=\mathrm{y}$

Purnamasari N, Ma'ruf MF. 2016. Faktor yang Mempengaruhi Partisipasi Peserta dalam Program Sekolah Lapangan Pengelolaan Tanaman Terpadu (SL-PTT) Padi di Desa Bedikulon Kecamatan Bungkal Kabupaten Ponorogo. Jurnal Publika. [Internet]. [04 Juni 2017]. Vol. 04 (3). Dapat diunduh dari http://jurnalmahasiswa.unesa.ac.id/index.php/publika/article/view/14650

Pusat Data, Statistik, dan Informasi, Kementerian Kelautan dan Perikanan, Statistik Kelautan \& Perikanan 2011, Jakarta: Kementerian Kelautan dan Perikanan, 2013, hlm. 255.

Rani M. 2016. Insurance Protetion for Fisherman. [Internet]. [19 Oktober 2017]. Riau (ID): Universitas Maaritim Raja Ali Haji. Dapat diunduh di http://ojs.umrah.ac.id/index.php/selat/article/download/146/149

Sadly A. 2004. Faktor-faktor yang mempengaruhi tingkat partisipasi peternak dalam penyuluhan di Kabupaten Mandailing Natal [Skripsi]. [Internet]. [22 Desember 2017]. Bogor (ID): Institut Pertanian Bogor. Dapat diunduh dari http://repository.ipb.ac.id/bitstream/handle/123456789/15796/D04asa.pdf?sequence $=2 \&$ isAllowed $=\mathrm{y}$

Sahawi, ME.2016. Partisipasi Masyarakat dalam Pengembangan Desa Wisata dan Tingkat Taraf Hidup Masyarakat (Desa Pasir Eurih, Kecamatan Tamansari, Kabupaten Bogor) [Skripsi]. [22 Desember 2017]. Bogor (ID): Institut Pertanian Bogor. Dapat diunduh dari http://repository.ipb.ac.id/bitstream/handle/123456789/81594/I16mel.pdf?sequence $=1 \&$ isAllowed $=\mathrm{y}$

Satria A. 2002. Pengantar Sosiologi Masyarakat Pesisir. Jakarta (ID): PT Pustaka Cidesindo.

Satria A. 2012. Pengantar sosiologi masyarakat pesisir. Jakarta (ID): Yayasan Pustaka Obor Indonesia.

Thaibah SR. 2015. Penentuan Premi Dan Cadangan Manfaat Pada Beberapa Jenis Asuransi Jiwa Dengan Memperhitungkan Biaya [Skripsi]. [Internet]. [22 Desember 2017]. Bogor (ID): Institut Pertanian Bogor. Dapat Diunduh http://repository.ipb.ac.id/bitstream/handle/123456789/80790/G15srt.pdf?sequence $=1 \&$ isAllowed $=\mathrm{y}$ 
Triyanti R, Firdaus W. 2016. Tingkat Kesejahteraan Nelayan Skala Kecil dengan Pendekatan Penghidupan Berkelanjutan di Kabupaten Indramayu. [Internet]. [29 Juli 2018]. Vol. 11(1): 2943. Dapat diunduh

https://www.google.co.id/search?q=jumlah+dan+kesejahteraan+nelayan\&oq=jumlah+dan+kese jahteraan+nelayan\&aqs=chrome..69i57.9429j0j7\&sourceid=chrome\&ie=UTF-8\#

Undang-Undang Republik Indonesia Nomor 45 Tahun 2009 tentang Perikanan. Pemerintah Republik Indonesia. Jakarta

Wijaksono S. 2013. Pengaruh Lama Tinggal terhadap Tingkat Partisipasi Masyarakat dalam Pengelolaan Lingkungan Permukiman. Jurnal Comtech. [Internet]. [07 Oktober 2017]. Vol. 4 No. 1. Dapat diunduh dari http://journal.binus.ac.id/index.php/comtech/article/view/2679/2085 